\title{
Evidence of the Presence of the Tobacco-Etch Virus in Puerto Rico
}

\section{López Matos ${ }^{2}$}

\section{INTRODUCTION}

Cigar-filler and chewing-tobacco plants presenting chlorotic and necrotic spots have been found in many fields in the cigar-filler and chewing-tobacco areas of Puerto Rico during the past 6 years. The number of affected plants increases by the end of the tobacco season, especially among tobacco planted in December or later. Very few cases were observed in the field at the beginning of the tobacco season. In only two cases have plants showing these symptoms been found in seedbeds since 1954 .

Chewing tobacco is more severely affected. This can be accounted for by the fact that chewing tobacco is topped earlier and the leaves are left for a longer period until they are mature and the plant is ready for harvest. Plants infected at an early stage of growth show many necrotic spots, arcs, or rings. Soon after the tobacco is topped the necrotic areas coalesce, form, ing holes that again coalesce, practically destroying the leaf (fig. 1, A, B, and $\mathrm{C}$ ). Chewing-tobacco leaves affected in this way are useless. The tobacco producer includes this disease in the group of diseases that he refers to as tabaco pinto, which is a general term applied to tobacco leaves with any type of lesion on them. The author has been referring to this disease as the salpicado del tabaco to distinguish it from other virus diseases.

Thinking it possible that this disease might be caused by the etch virus, studies were initiated to identify the virus. This paper reports work on the identification of the virus.

\section{SYMPTOMS}

The variation in the cigar-filler and chewing-tobacco varieties in Puerto Rico presents difficulties in the description of the symptoms of tobacco-etch virus. llants have been found showing symptoms very similar to those described by Johnson $(3)^{3}$ for different strains of the etch virus, such ats "etch", "etch + ", "severe etch", and "coarse etch" found in Kentucky and Georgia. Some field-infected plants present fine etching on older leaves (fig. 1,D). Some of these plants also present suckers with chlorotic spots

1 Contribution from the Gurabo Sulsstation.

2 Assistant Pathologist, Agricultural Experiment Station, University of Puertn Rico, Gurabo, l'.R. Thanks are due J. linricue Pérez for carrying out the serological tests.

3 Italic numbers in parentheses refer to Jiterature Cited, p. 181. 

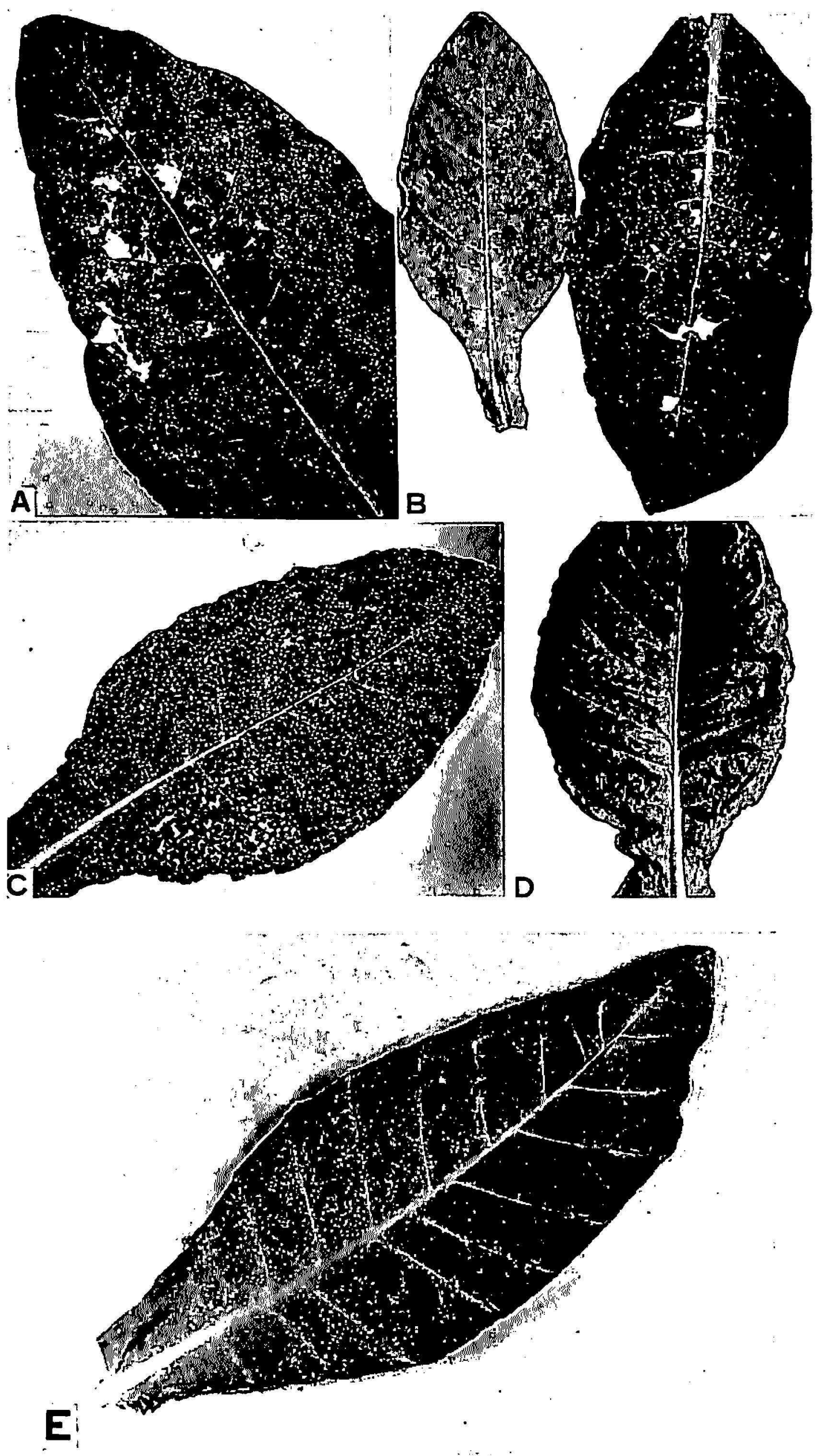

FIg. 1.-Tobacco leaves showing symptoms of the virus disease: $\mathrm{A}, \mathrm{B}$, and $\mathrm{C}$ are leaves from field-infected plants showing necrotic areas and holes resulting from coalescence of small necrotic spots and ares and/or rings. I) and lis show leaves from field-infected plants showing fine etch and ares. 
and ares or lines in the younger leaves. Some of these spots become reddishbrown and then gray or white as the leaf becomes older. Other plants present larger necrotic spots and arcs, or small rings in the older leaves (fig. $1, \mathrm{E})$. These symptoms may be found alone or accompanied by vein necrosis in some plants (fig. 1,A). Other plants may show vein necrosis with a few necrotic spots (fig. 2,A). Others still show more necrotic rings than necrotic spots in the older leaves. Some of these plants may also present chlorotic spots and arcs in the younger leaves.

Plants may have all leaves affected or only one or two. Other plants may show two older leaves with etch symptoms and three or four leaves free of spots, and then two or three of the younger leaves with chlorotic, rustybrown, or necrotic spots. Some plants may show severe symptoms of etch plus distortion of the younger leaves and stunting. However, these cases are very rare.

Figure 2,B shows a leaf of a field-infected plant presenting many small necrotic rings. The sap of this plant was rubbed on the leaves of small seedlings of tobacco variety Virginia 12 . Figure 2,C shows one of the seedlings with vein necrosis and necrotic arcs and spots in the inoculated leaves and chlorotic and necrotic or reddish-brown spots and ares in the younger leaves and a tendency of these leaves to curve back.

Figure 2,D shows the sime plant 3 weeks later. This plant presented chlorotic spots and arcs in the younger leaves. As the leaf became older these spots became rusty brown and then gray or whitish. The borders of the leaves also show the tendency to curve back. This tendency is more marked in inoculated plants. Not all plants inoculated with the same inoculum present symptoms in the same fashion. Symptoms are more marked in some plants than in others. Very few chlorotic spots are found on some plants. More chlorotic spots may appear on these plants. If the plants are kept growing vigorously at all times, chlorotic and rusty-brown or necrotic spots can be found at any time.

\section{MATERIALS AND METIODS}

Plants used in these studies were grown in clay pots in the greenhouse using steam-sterilized soil with the same amount of fertilizer per plant. Insects were controlled with sprays of Parathion (15 percent) at the rate of 1 pound per 50 gallons of water, applied once every other day. Silicon carbide grit No. 400 was used as an abrasive when virus transmissions were made by rubbing the sap of infected plants on the leaves of healthy ones. Plants were inoculated when they had three to four leaves and were growing vigorously.

The study of the virus was made by means of differential hosts, following the key proposed by Valleau (6), and, serologically, by following the precipitin reaction test described by Bawden (1). 

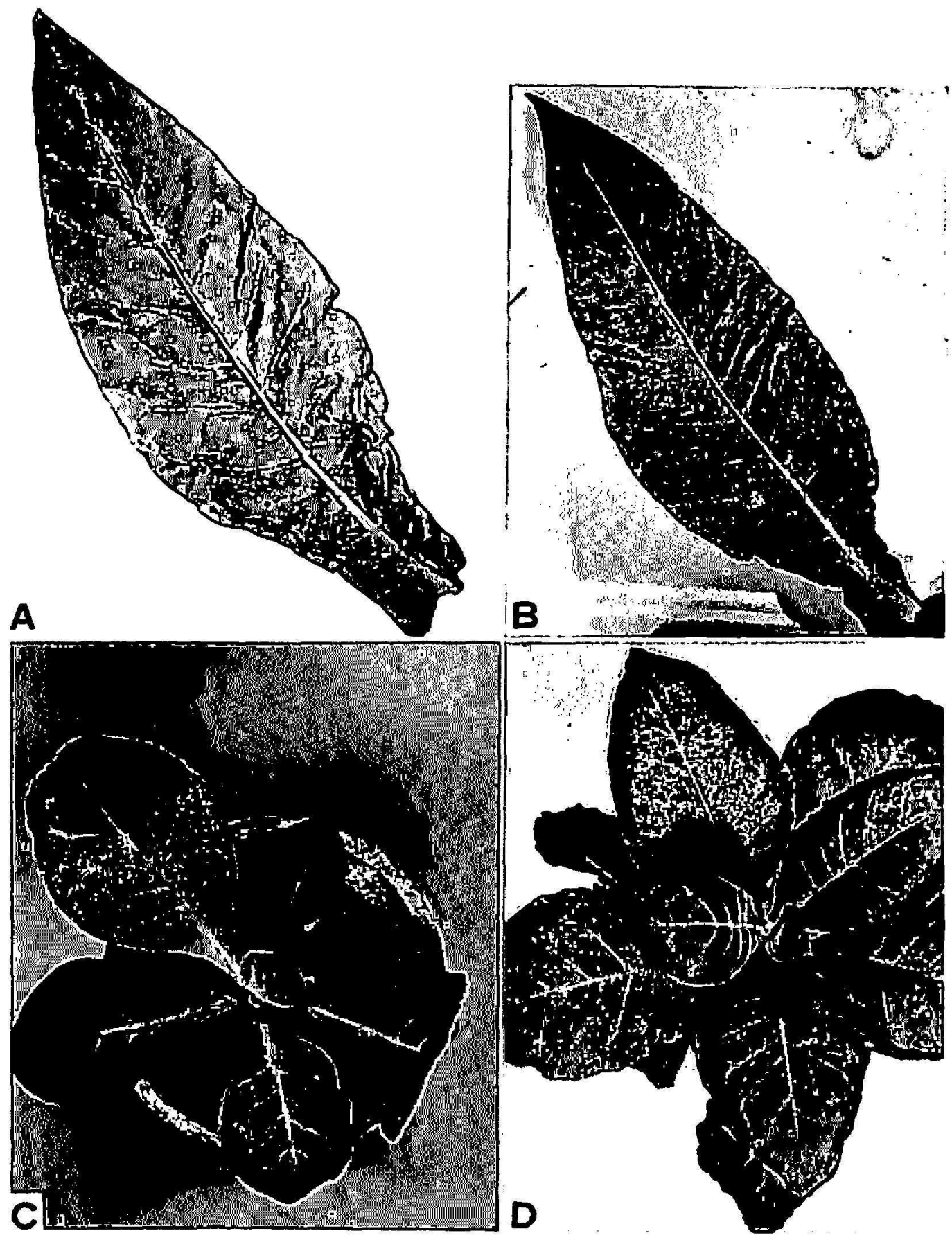

Fig. 2.-Tobaceo leaves showing symptoms of the virus disease: A, Leaf from a field-infected plant showing vein necrosis and a few necrolic spots. B, Leaf from a field-infected plant showing many necrotic ares and small rings. C, A tobaceo seedling inoculated with sap obtained from the leaf of the field-infected plant shown in $B$. The inoculated leaf presents fine vein necrosis, the younger leaves present chlorotic spots and ares, and stunting. 1), The same plant as in C 3 weeks later. 
The following operations were made following the key proposed by Valleau:

1. Determination of the destruction of the infectivity of the virus by air-drying the infected leaves: The infected tobacco leaves were air-dried at room temperature. Then they were crushed in water using approximately twice as much water as the volume of the crushed leaves. The extract was rubbed on the leaves of healthy plants of cigar-filler tobacco variety Virginia 12. Fifteen plants were inoculated. An equal number of plants were left uninoculated and used as a control. Fifteen plants of tobacco hybrids carrying the Glutinosa type of resistance to the common tobacco-mosaic virus were also inoculated to insure that the tobacco-mosaic virus was not present.

2. Determination of transmission of the virus by plant sap: Juice obtained from samples of field-infected plants of both chewing- and cigarfiller tobacco brought from different parts of the tobacco-growing area was rubbed on the leaves of healthy plants of cigar-filler tobacco. Table 1 indicates the place of origin of the sample and the variety of tobacco from which it was obtained.

3. Infectivity on cucumbers: Leaves of cucumber of the variety Puerto Rico 39 were rubbed with sap from each of the leaf samples obtained in the field.

Twelve leaf samples from plants having symptoms of etch were tested serologically. Table 1 gives the description of each sample tested and the results of the tests. Five samples were taken from plants inoculated in the greenhouse. The inoculum for these plants had been obtained from the same plant from which sample No. 1 in table 1 was obtained. The other seven samples (Nos. 2 to 8 in table 1) were taken from suckers of field-infected plants. The samples were ground in clean sterilized mortars and the crude sap extracted by squeezing each macerate through pieces of doublelayer cheesecloth. The saps were then clarified by low-speed centrifugation. Each sap was mixed separately in a precipitin tube with specific antisera for the virus of tobacco severe etch, tobacco mosaic, pepper mosaic, tobacco ringspot, potato virus $\mathrm{X}$, and normal rabbit serum.

Insect-transmission tests were also made using the aphid Myzus persicae Sulz. as the vector. Table 2 shows the results obtained in the six greenhouse trials made.

No attempt was made to control temperature and humidity. The seedbeds were kept in insect cages. In trials Nos. 1 to 5 the plants were grown in 4-inch clay pots. Fifteen plants were used in trials Nos. 1 to 4 . Forty plants were used in trial No. 5. All plants in trials Nos. 1, 2, and 5 were kept in insect cages $4^{\prime} 6^{\prime \prime}$ wide; $2^{\prime} 6^{\prime \prime}$ long; and $3^{\prime}$ high, consisting of Lumite in an aluminum frame (fig. 3,A). In trials Nos. 1 and 2, plants were about 
TABLE 1.-Results of the inoculation of the virus in tobacco varieties and in cucumber, and place of origin of the sample and its serological reaction

\begin{tabular}{|c|c|c|c|c|c|c|c|c|c|}
\hline \multirow{2}{*}{ Sample No. } & \multirow{2}{*}{$\begin{array}{l}\text { Variety and type of } \\
\text { tobacco }\end{array}$} & \multirow{2}{*}{ Place of origin } & \multirow{2}{*}{$\begin{array}{l}\text { Number of } \\
\text { plants of } \\
\text { Virginia } 12 \\
\text { inoculated and } \\
\text { infected }\end{array}$} & \multirow{2}{*}{$\begin{array}{l}\text { Symptoms in } \\
\text { Virginia } 12\end{array}$} & \multirow{2}{*}{$\begin{array}{l}\text { Plants of } \\
\text { cucumber } \\
\text { inoculated }\end{array}$} & \multicolumn{4}{|c|}{ Serological reaction: } \\
\hline & & & & & & $\begin{array}{l}\text { Samples } \\
\text { Tested }\end{array}$ & TMV: & MV' & Etch \\
\hline 1 & $\begin{array}{l}\text { Tabaco del pais, } \\
\text { chewing }\end{array}$ & $\begin{array}{l}\text { Barrio Coto, Isabela, } \\
\text { Francisco Chá- } \\
\text { vez's Farm }\end{array}$ & 5 & Etching & 6 & 5 & - & - & $\begin{array}{l}3+ \\
2-\end{array}$ \\
\hline 2 & $\begin{array}{l}\text { Virginia 12, cigar } \\
\text { filler }\end{array}$ & $\begin{array}{l}\text { Barrio Cañabón, } \\
\text { Caguas, Station } \\
\text { Farm }\end{array}$ & 6 & do. & 9 & 1 & - & - & + \\
\hline 3 & do. & $\begin{array}{l}\text { Barrio Rincón, Gu- } \\
\text { rabo, Station } \\
\text { Farm }\end{array}$ & 4 & do. & 6 & 1 & - & - & - \\
\hline 4 & Orama, cigar filler & $\begin{array}{l}\text { Barrio Cordilleras, } \\
\text { Ciales }\end{array}$ & 6 & do. & 6 & 1 & - & - & + \\
\hline 5 & $\begin{array}{l}\text { Tabaco del pais, } \\
\text { chewing }\end{array}$ & $\begin{array}{c}\text { Barrio Terranova- } \\
\text { Quebradillas }\end{array}$ & 6 & do. & 6 & 1 & 一 & - & - \\
\hline 6 & $\begin{array}{l}\text { Tabaco del pais, } \\
\text { chewing }\end{array}$ & Barrio Coto, Isabela & 4 & do. & 6 & 1 & - & - & + \\
\hline 7 & do. & $\begin{array}{l}\text { Barrio Guerrero, Isa- } \\
\text { bela, M.A. Gue- } \\
\text { vara's Farm }\end{array}$ & 4 & do. & 6 & 1 & - & - & - \\
\hline 8 & $\begin{array}{l}\text { Chewing tobacco } \\
\text { hybrid }\end{array}$ & $\begin{array}{l}\text { Station Farm, Isa- } \\
\text { bela }\end{array}$ & 4 & do. & 6 & 1 & - & - & - \\
\hline
\end{tabular}

${ }^{2}$ Serological test was made by using a sample taken from the top leaves of field-infected plants, except in sample No. 1 in which the 5 samples were taken from plants which had been inoculated in the greenhouse, the original plant having been found at the farm of Don Francisco Chávez at Barrio Coto, Isabela.

${ }^{3} \mathrm{TMV}=$ tobacco mosaic virus.

${ }^{4} \mathrm{MV}=$ mottle virus. 
6 inches in height and growing vigorously. In trials Nos. 3 and 4 the plants were grown in insect cages $24^{\prime \prime}$ wide; $171 / 2^{\prime \prime}$ long; and 101/2" high, consisting of Lumite with a glass window in a wooden frame (fig. $3, B$ ). In trials Nos. 3 and 4, insects were placed when the plants were about 3 inches in height. In trial No. 5 the insects were placed when the plants were about 6 inches in height. In trial No. 6 the plants were grown in 2-inch clay pots, and each plant was protected with individual insect cages. The eages were

TABLE 2.-Results in tests for the transmission of the etch virus to Virginia 12 variety by placing 25 aphids (Myzus persicae Sulz.) on each plant

\begin{tabular}{|c|c|c|c|c|c|c|}
\hline $\begin{array}{l}\text { Trial } \\
\text { No. }\end{array}$ & $\underset{\substack{\text { Numb } \\
\text { of } \\
\text { plants }}}{\mid}$ & $\begin{array}{l}\text { Date of } \\
\text { inoculation }\end{array}$ & $\left|\begin{array}{c}\text { Number } \\
\text { of } \\
\text { infected } \\
\text { plants }\end{array}\right|$ & $\begin{array}{l}\text { Date of first } \\
\text { symptom }\end{array}$ & Symptoms & Remarks \\
\hline $\begin{array}{l}1 \\
2\end{array}$ & $\begin{array}{l}15 \\
15\end{array}$ & $\begin{array}{l}\text { Nov. } 17, \text { '54 } \\
\text { Dec. } 9, ' 54\end{array}$ & $\begin{array}{l}1 \\
2\end{array}$ & $\begin{array}{r}6 \text { days } \\
1 \text { at } 6 \text { days } \\
1 \text { at } 7 \text { days }\end{array}$ & $\begin{array}{l}\text { Etching } \\
\text { do. } \\
\text { do. }\end{array}$ & $\begin{array}{c}\text { Plants near } 6^{\prime \prime} \text { in height } \\
\text { Do. }\end{array}$ \\
\hline 3 & 15 & Jan. 8, '55 & 0 & $\overline{\mathrm{C}}$ & - & Plants near $3^{\prime \prime}$ in height \\
\hline 4 & 15 & Jan. 8, '55 & 2 & $\begin{array}{l}1 \text { at } 6 \text { days } \\
1 \text { at } 5 \text { days }\end{array}$ & do. & Do. \\
\hline $\mathbf{5}$ & 40 & Jan. 23, '55 & 2 & $\begin{array}{l}1 \text { at } 9 \text { days } \\
1 \text { at } 11 \text { days }\end{array}$ & & $\begin{array}{l}\text { Plants were from same } \\
\text { group as in } 3 \text { and } 4 \\
\text { and not growing vig- } \\
\text { orously near } 6^{\prime \prime} \text { in } \\
\text { height }\end{array}$ \\
\hline 6 & 16 & Jan. 15, '58 & 5 & 8 days & do. & $\begin{array}{l}\text { Plants were very small. } \\
\text { Leaves were the size } \\
\text { of a } 10 \text { cent coin or } \\
\text { smaller. }\end{array}$ \\
\hline
\end{tabular}

${ }^{1}$ Indicates the number of days after inoculation that each of the plants, the numbers of which appear in the preceding column, developed the first symptoms.

$2^{\prime \prime}$ wide, $2^{\prime \prime}$ long, and $7^{\prime \prime}$ high, consisting of plastic sides and the top of Lumite. The top had a small hole with a cork stopper (fig. 3,C).

Twenty-five insects per plant were used in all trials. The insects were kept for 72 hours feeding on the infected plants. After feeding they were fasted for half an hour and placed on the healthy plants for 24 hours. To transfer the insects from the infected to the healthy plants, they were collected with a small sterile camel-hair brush and placed in a sterile petri dish. After fasting for 30 minutes the aphids were placed on the leaves of the healthy plants by means of another small sterile camel-hair brush. The leaves of the plants to which the insects were transferred were approximately the size of a 10 cent coin, or less. After feeding for 24 hours on the healthy plants the insects were killed with a spray of 15-percent Parathion, at the rate of 1 pound per 50 gallons of water. 

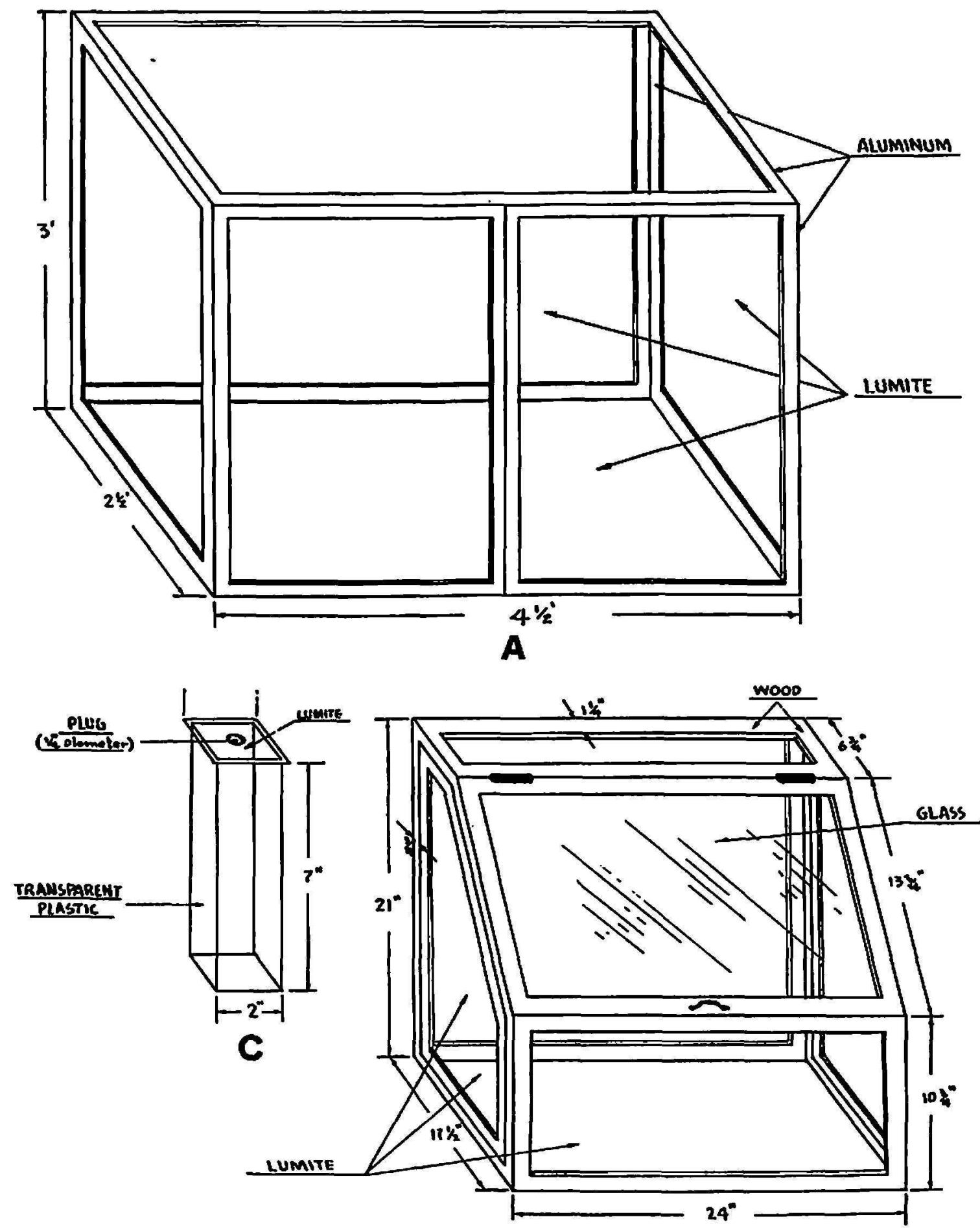

B

Fig. 3.-A, B, and C: Drawings of three types of insect cages used for insect transmission of the virus.

Serological tests and differential host plants such as Holmes' Samsoun tobacco and Large Bell Hot pepper were used to confirm the presence of the virus under study and to eliminate the possibility of having another virus present, such as the tobacco-mosaic virus or the tobacco-mottle virus. 
The Holmes' Samsoun tobacco carries the factor for resistance to the tobacco-mosaic virus present in Nicotiana glutinosa (Holmes 1938) (2). The leaves develop necrotic lesions when inoculated with the tobacco-mosaic virus. Capsicum frutescens var. Large Bell Hot develops systemic necrosis followed by defoliation and death of the plant when inoculated with the tobacco-mottle virus (Roque and Adsuar 1941) (5). The differential host plants were used in trials Nos. 1 to 5 . Both the differential host plants and the serological tests were used in trial No. 6. Serological tests were made to detect the presence of the following viruses: Tobacco ringspot, tobacco mosaic, potato $\mathrm{X}$, and the pepper mosaic, besides severe etch.

\section{RESULTS AND CONCLUSIONS}

No symptoms were produced on plants of Nicotiana tabacum var. Virginia 12 nor of the Holmes' Samsoun variety inoculated with the juice extracted from air-dried leaves of infected plants. This indicated that the tobacco-mosaic virus was not present.

The virus is easily transmitted to tobacco by plant sap. $N$. tabacum var. Virginia 12 developed symptoms very similar to those observed in field-infected plants. The symptoms were more marked in some plants. $N$. tabacum var. Holmes' Samsoun presented vein-clearing and light chlorosis of the younger leaves. Tiny necrotic rings appeared as the leaves became older. These symptoms were followed by the presence of necrotic spots, arcs, and rings. Again, some of the plants presented more marked symptoms than others. Similar symptoms were observed with all samples of field-infected plants. The absence of infectivity of necrotic lesions typical of tobaccomosaic virus on Holmes' Samsoun tobacco showed that the virus causing the disease was not the tobacco-mosaic virus. No symptoms were produced on cucumber, Cucumis sativus var. Puerto Rico 39, inoculated with the virus with any of the samples tested.

Plants inoculated with juice of plants from samples Nos. 2 and 3 did not produce any infection on peppers, Capsicum frutescens var. Large Bell Hot, while juice from plants of samples Nos. 1, 4, 5, 6, 7, and 8 produced mottling and distortion of the leaves. Absence of systemic necrosis followed by death of the plants indicated that the pepper-mosaic and tobacco-mottle virus were not present.

Three of the seven samples of field-infected plants tested serologically gave a strong precipitate with the serum against the etch virus. Of the five plants which had been inoculated with juice extracted from a field-infected plant, the samples of three also gave a strong precipitate with the serum against the etch virus. None of the samples reacted with any of the other viral antisera used in the tests, nor with normal rabbit serum.

The virus under study was found to be transmitted by the aphid, Myzus 
persicae. In five out of six trials the disease was transmitted. Results are given in table 2. First symptoms developed from 5 to 11 days after placing the insects on the healthy plants. The percentage of infection varied from 4 to 31 . Kassanis (4) found that severe etch virus is transmitted by Myzus persicae and $M$. circunflexus.

From the results of the test made following Valleau's method of identification of viruses in tobacco and from the results of the serological tests, it is concluded that the virus that causes el salpicado del tabaco in Puerto Rico by developing chlorotic spots followed by necrotic spots, arcs, and rings in the leaves, is related to the etch virus. It is also concluded that besides the severe-etch strain we may have the mild strain and possibly the coarse-etch strains.

\section{SUMMARY}

A new virus disease was found in cigar-filler and chewing-tobacco plants in Puerto Rico, in 1954. The infected plants developed chlorotic spots on the younger leaves followed by the presence of necrotic spots, ares, and sometimes rings as the leaves became older. The younger leaves also appeared slightly chlorotic. Chewing tobacco is more severely affected than cigarfiller tobacco. The virus is easily transmitted mechanically by plant sap. It was also found to be transmitted by the aphid Myzus persicae. The virus was identified by using the method proposed by Valleau (6) to identify viruses that are found causing disease in commercial plantings of tobacco, and by serology, using the method recommended by Bawden (1). Antisera for tobacco severe-etch virus was used. It was found that the virus that causes what is referred to as el salpicado del tabaco in Puerto Rico is related to the etch virus. The variety of symptoms observed suggest that besides severe etch the mild- and coarse-etch strains of the virus may also be present in Puerto Rico.

\section{RESUMEN}

Una nueva enfermedad virosa que ataca las plantas de tabaco para tripa y para hilar se encontró en Puerto Rico en 1954. Las plantas atacadas por esta enfermedad desarrollan manchas cloróticas en sus hojas seguidas de puntos, arcos $\mathrm{y}$, a veces, pequeños anillos necróticos. Las hojas más tiernas se tornan ligeramente cloróticas. Es el tabaco de mascar el que se afecta más severamente debido a esta enfermedad. El autor ha llamado esta enfermedad el salpicado del tabaco para así diferenciarla de otras enfermedades también causadas por otros virus.

Al principio de la cosecha se encontraron casos aislados de plantas atacadas por la enfermedad en los plantíos. Se notó que la incidencia aumenta en las siembras tardías o sea las que se hacen en diciembre, o más tarde. Tal parece que la enfermedad se ha extendido durante los últimos años. 
El virus que causa esta enfermedad se trasmite mecánicamente por medio de la savia. También se encontró que el agente que la trasmite es el áfido Myzus persicae Sulz.

El virus se identificó por medio del método propuesto por Valleau (6) para identificar los virus que causan enfermedades en los plantíos comerciales de tabaco y también por medio de los métodos serológicos recomendados por Bawden (1). En la prueba se usó un antisuero para el virus que causa el "severe etch" al tabaco. Se encontró que el virus que causa el salpicado del tabaco en Puerto Rico es una cepa del virus "etch". La variación en los síntomas observados indican que hay la posibilidad de que existan varias cepas del virus "etch" en Puerto Rico.

\section{LITERATURE CITED}

1. Bawden, F. C., Plant Viruses and Virus Disease, 3d ed., Chronica Botanica Co. Waltham, Mass., 1950.

2. Holmes, F. O., Inheritance of resistance to tobacco mosaic disease in tolsacco, Phytopath. 28 553-61, 1938.

3. Johnson, E. M., Virus Diseases of Tobacco in Kentucky, Agr. Exp. Sta. Res. Bul. 306, 1930.

4. Kassanis, B., Intranuclear inclusions in virus-infected plants, Ann. Appl. Biol. 26 $705,1939$.

5. Roque, A. and Adsuar, J. Studies on the mosaic of peppers (Capsicum frutescens) in Puerto Rico, J. Agr. Univ. P.R. 25 (4) 54, 1941.

6. Valleau, W. D., Classification and nomenclature of tobacco viruses, Phytopath. 30 820-30, 1940. 